\title{
Effects of Lunar Phases and Other Variables on CPUE of European Pilchard, Sardina pilchardus, Caught by Purse Seine in the Eastern Mediterranean
}

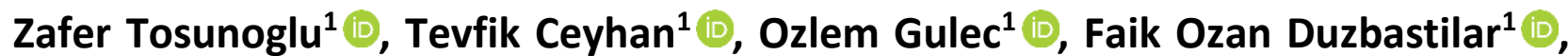 \\ Muharrem Hakan Kaykac $\left.{ }^{1, *} \mathbb{(}\right)$, Celalettin Aydin ${ }^{1}\left(\mathbb{D}\right.$, Gülnur Metin ${ }^{1}$
}

${ }^{1}$ Ege University, Faculty of Fisheries, 35100, Bornova, Izmir, Turkey

\begin{abstract}
How to cite
Tosunoglu, Z., Ceyhan, T., Gulec, O., Duzbastilar, F.O., Kaykac, M.H, Aydin, C., Metin G., (2021). Effects of Lunar Phases and Other Variables on CPUE of European Pilchard, Sardina pilchardus, Caught by Purse Seine in The Eastern Mediterranean. Turkish Journal of Fisheries and Aquatic Sciences, 21, 283-290. http://doi.org/10.4194/1303-2712-v21_6_03
\end{abstract}

\section{Article History}

Received 02 December 2020

Accepted 16 March 2021

First Online 19 March 2021

\section{Corresponding Author}

Tel.: +905302120505

E-mail:m.hakan.kaykac@gmail.com

\section{Keywords}

European sardine

Lunar Effects

Sea Surface Temperature

Generalized Additive Modelling

Aegean Sea

\begin{abstract}
European pilchard Sardina pilchardus (Walbaum, 1792) is one of the most dominant small pelagic landed by purse seine in Turkey as well as Mediterranean. In this study, we aimed to identify relationships between the seasonally adjusted CPUE and changes of the sea surface temperature (SST), fishing area, moon phase, and light used in the purse seine fishery to understand the impact of changes on the CPUE of pelagic fishes, especially S. pilchardus, by a total of 214 operations in Izmir Bay, Aegean Sea. The effect of the parameters on the Sardine CPUE, expressed in terms of kg (haul day) ${ }^{-1}$, was examined by means of the Generalized Additive Modelling (GAMs) techniques. The CPUE values for S. pilchardus were between $0-16800 \mathrm{~kg}$ (haul day) $)^{-1}$ and the mean CPUE was $1844.3 \pm 176.6 \mathrm{~kg}$ (haul day) ${ }^{-1}$. The smallest median was $441 \mathrm{~kg}$ (haul day $^{-1}$ for full moon and the differences between the CPUE values of lunar phases were statistically significant $(p<0.05)$. Furthermore, there is a linear relationship between CPUE and SST. In conclusion, the CPUE varied under hydrographic variables mostly SST for sardine purse seine fishery in the Aegean Sea.
\end{abstract}

\section{Introduction}

European pilchard Sardina pilchardus (Walbaum, 1792 ) is the one of the most dominant small pelagic fish landed by purse seine in Turkey as well as the other Mediterranean countries. Turkey had a highest landing $322173 \mathrm{mt}$ by superior fishing fleet across the General Fisheries Commission for the Mediterranean (GFCM) area of application in 2017 (FAO, 2018). This was obtained by 15406 (17.8\%) fishing vessels with 174700 gross tonnages and $1197548 \mathrm{~kW}$ engine power. Besides, the other pelagic fish species (e.g. anchovy Engraulis encrasicolus, chub mackerel Scomber japonicus, Atlantic mackerel Scomber scombrus, bogue Boops boops), the sardines (S. pilchardus and Sardinella aurita) are targeted fish by purse seine fishery in the Aegean Sea. A total of 66 purse seiners, of which the most were registered to Izmir port, catch fish along the Aegean coast of Turkey.

Environmental conditions such as temperature, salinity etc. play an important role in the temporal and spatial distribution and abundance of the small pelagic fish. The effect of changing conditions on the spatial distribution of fish stocks or their availability to fishing fleets have been studied many times for various fishing gears (Gang et al., 2013; Abdellaoui et al., 2017; Hure \& Mustać, 2020; Quattrocchi \& Maynou, 2017; Torrejónmagallanes et al., 2019; Wise et al., 2019, Yang et al., 2019). In order to explain fluctuations in CPUE of the sardine fishery, the relationships between CPUE and 
environmental factors were modelled with nonlinear models (GAM) by Borges et al. (2003). Furthermore, Abdellaoui et al. (2017) analysed the seasonal and trends of time series of CPUE linked to environmental parameters (i.e., sea surface temperature and chlorophyll-a) via GAM as well. They found the temperature is the most important parameter affecting abundance. Quattrocchi and Maynou (2017) also reported the relationship between landing per unit effort and Western Mediterranean Oscillation index, sea surface temperature, salinity and the Zonal and Meridional Currents with GAMM.

Dependence of landing in purse seine fishing on the environmental factors makes it vulnerable to environmental changes; as a result, the landing of the species is highly variable. In this study, Generalized Additive Model (GAMs), incorporating the nonlinear correlation structure, was used to identify relationships between the seasonally adjusted CPUE and changes of the sea surface temperature (SST), fishing area, moon phase and light using in the Izmir Bay purse seine fishery in order to understand the impact of changes on the CPUE of pelagic fishes, especially S. pilchardus, in this area.

\section{Material and Methods}

In this study, daily landing data were obtained from a commercial purse seiner, Afala (23.4 m LOA and 313.3 $\mathrm{kW})$. The vessel was equipped with hydro acoustic systems (Two types of sonar $-107 \mathrm{kHz} \mathrm{CH}-84$ model and $160 \mathrm{kHz} \mathrm{CH}-28$, echo-sounder $50-200 \mathrm{kHz}$ freq.). The light vessel Ayyıldız-2 is $11.8 \mathrm{~m} \mathrm{LOA}$ and $99.2 \mathrm{~kW}$-main engine, $30 \mathrm{~kW}$-generator. The generator output setting is regulated to 8000 watts. The purse seine net consists of 5 bulk and 1 bunt, resulting in length of $750 \mathrm{~m}$ and depth of $164 \mathrm{~m}$. Though the targeted fish are small pelagic such as sardine and anchovy, the mesh size of the purse seine net is $13 \mathrm{~mm}$.

The data collected during each fishing trip including date, fishing area (Figure 1), light or sonar usage and catch record in 2018-2019 fishing season that covers the time period between September $1^{\text {st }}$ and April $15^{\text {th }}$. The lunar cycle was classified into four periods as new moon, first quarter, full moon and last quarter. Sea Surface Temperature (SST) data was obtained from the General Directorate of the Meteorological Service (GDMS). The CPUE was calculated from three parameters as below:

$$
\begin{gathered}
F=H \cdot D \\
\text { CPUE }=B \cdot F^{-1}
\end{gathered}
$$

Where $F$ is fishing effort, $H$ is number of hauling, $D$ is fishing day and $B$ is biomass of sardine.

The effect of variables on the CPUE of sardines, expressed in terms of $\mathrm{kg} \cdot 1$ haul $^{-1} \cdot 1$ day $^{-1}$, was examined by means of the Generalized Additive
Modelling (GAMs) techniques (Hastie \& Tibshirani, 1990). Generalized Additive Models (GAMs) with Tweedie family (Tweedie, 1984; Dunn \& Smyth, 2005; Wood et al., 2016) and log link function was used to evaluate the relationship between CPUE with other parameters besides lunar phase. There are few zero CPUE, hence Tweedie is able to avoid multiple-stage modelling of zero inflated data and allows to model jointly the probability of presence and the non-zero sampled quantity (Shono, 2008; Lecomte et al., 2013). Furthermore, the fitted GAMs were estimated using maximum likelihood-based smoothness selection procedures, in particular the restricted maximum likelihood (REML). The smoother function used was a penalized cubic regression spline and model fitting was accomplished using the "mgcv" library (Wood, 2006) under the R language environment ( $R$ Core Team, 2017). The procedure automatically selects the degree of smoothing based on the Generalized Cross Validation (GCV) score, which is a proxy for the model predictive performance. The maximum degrees of freedom for each smoothing term, measured as the number of knots (k), was set to 9 (i.e., $\mathrm{k}=10$ in the GAM formulation). The QQ plot of the deviance residuals and deviance residuals vs. fitted were also plotted for model checking (Pedersen et al., 2019). Thus, the form of the GAM used was:

$$
\text { CPUE } \sim \mathrm{a}+\mathrm{MP}+\mathrm{A}+\mathrm{L}+\mathrm{s}(\mathrm{SST})+\mathrm{e}
$$

where, $a$ is the intercept, MP is moon phase, $A$ is area, $L$ is a factor variable ("using a light"), SST is Sea Surface Temperature, and $s$ indicates the smoother function of the corresponding independent variable and $\mathrm{e}$ is a random error term.

Statistical inference was based on the $95 \%$ confidence level.

\section{Results}

The CPUE values for $S$. pilchardus were between $0-16800 \mathrm{~kg}$ (haul day) ${ }^{-1}$ and the mean CPUE was $1844.3 \pm 176.6 \mathrm{~kg}$ (haul day) ${ }^{-1}$. Summary statistics of CPUE by moon phases are shown in Table 1 . The smallest median was $441 \mathrm{~kg}$ (haul day) ${ }^{-1}$ for full moon and there are differences between the CPUE values of lunar phases (Figure 2). The CPUE analysis on areas showed that there were large variations between areas regarding the median CPUE estimates (Figure 3). Moreover, the use of light is more common in Aegean Sea (Figure 4). The mean CPUE of operations with light was $2217 \pm 210 \mathrm{~kg}$ (haul day) ${ }^{-1}$. In fact, the mean of CPUE of operations with sonar was just $343 \pm 118 \mathrm{~kg}$.

The QQ plot of the deviance residuals and deviance residuals vs. fitted plot of the applied GAM model show that the distribution seems to fit the observed data well (Figure 5). There are exceptions at low values, so the deviance residuals are larger than predicted by the theoretical quantiles (Figure 5a). There also does not 
seem any inappropriateness of the fitted model in the residual vs. fitted values (Figure $5 b$ ), except for a line of residuals at the lowest values, which correspond to all of operations that had $0 \mathrm{~kg}$ sardine catch. The analysis of deviance table indicated that all factors were significant (Table 2). Furthermore, there was a linear relationship between CPUE and SST (Figure 6).

\section{Discussion}

Sardine was the highly dominated landed fish species in the Aegean Sea purse seine fishery e.g. in 1993-1994 fishing season, it constituted near approximately half of the landed fish species (Hoşsucu et al., 1994). At the present time, Tosunoğlu et al. (2018) estimated this ratio as $54 \%$ for one vessel with a total of $786731 \mathrm{~kg}$ landed fish in Izmir Bay. In this study, the CPUE values for $S$. pilchardus were calculated between 0 - $16800 \mathrm{~kg}$ (haul day) ${ }^{-1}$ and the mean CPUE was calculated as $1844.3 \pm 176.6 \mathrm{~kg}$ (haul day) ${ }^{-1}$ for one vessel in 2018-2019 fishing season with 136 working days, 214 valid operations. According to non-official statistics of the Aegean Region Purse Seine Fishers Association, each of the fifty-purse seiner captured between 750 and $1200 \mathrm{mt}$ of fish in the Aegean Sea (from Çanakkale to Bodrum) during the 2017-2018 fishing season. From all records and studies, it is roughly claimed that Aegean purse seiners caught about 50000

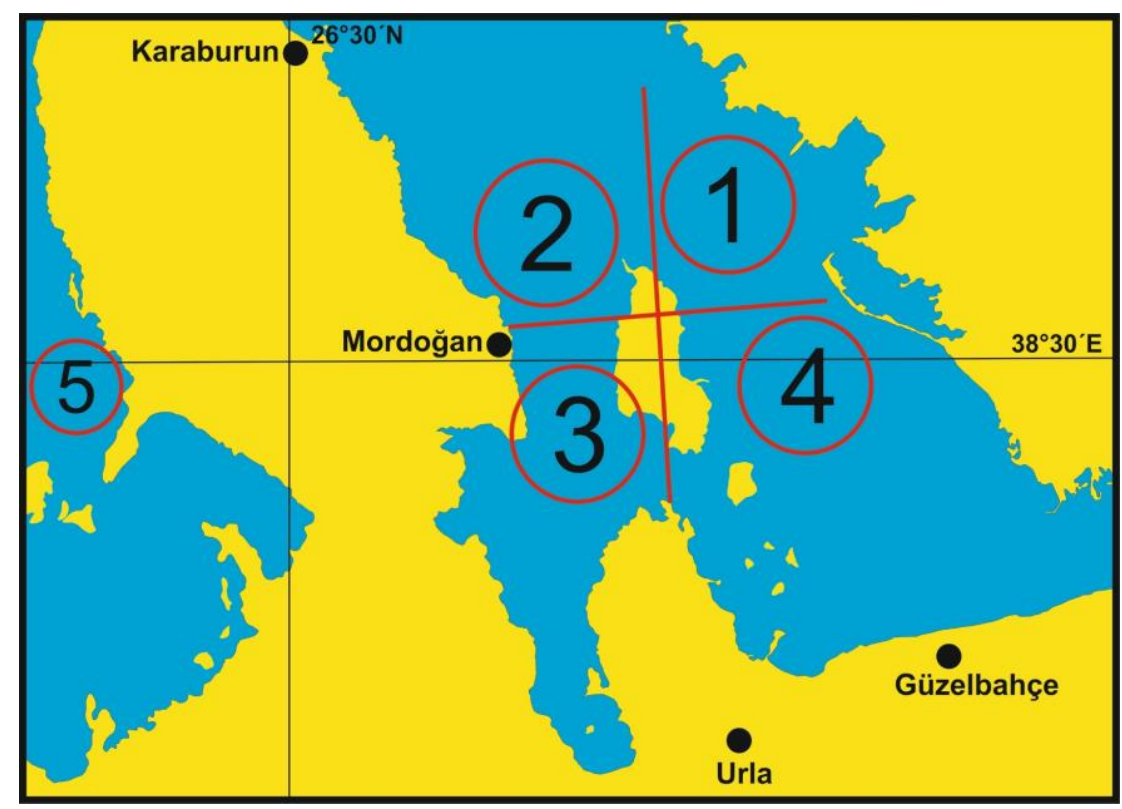

Figure 1. Purse seine fishing areas in Izmir Bay and adjacent waters in the Aegean Sea, Turkey.

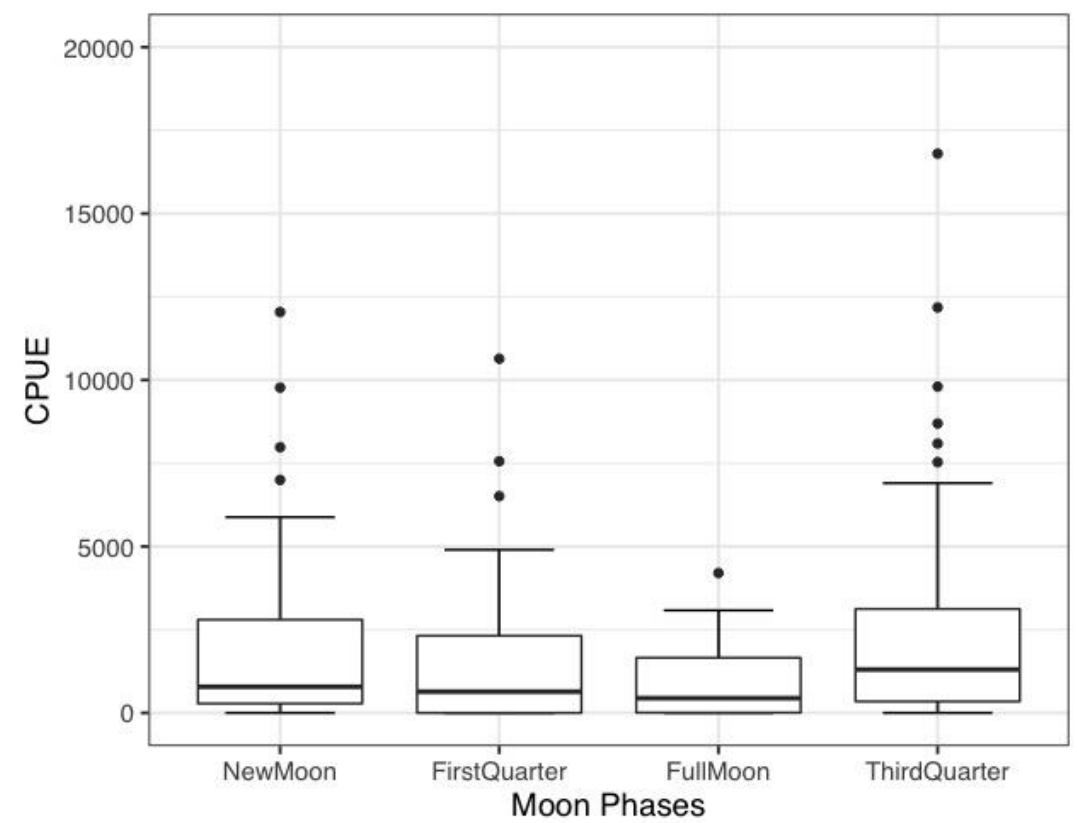

Figure 2. CPUE values of sardine purse seine by moon phase. 
tonnes fish in each year from nineteenths to nowadays and half of the landed species is sardine. Experienced purse seine skippers also confirmed these landings with daily and seasonally routine observations (personnel com. member of the Aegean Region Purse Seine Fishers Association). On country scale, the landing of European pilchard has been decreasing, so anchovy already took the first place with 33 percentages for the purse seiners in the Aegean Sea. The Climate shifting played a significant role in shaping habitat and resource partitioning for anchovy in the Aegean Sea (Gücü, 2012) with the highest landing (TurkStat, 2019). These important changes of the landing yields of two important small pelagic fish should also be investigated not only biological studies but also environmental variables, which affect the population structure and biomass.
In this study, the lowest and highest mean of CPUEs were found as $885 \pm 176.6 \mathrm{~kg}$ (haul day) ${ }^{-1}$ for full moon and $2550 \pm 438.6 \mathrm{~kg}$ (haul day) ${ }^{-1}$ for third quarter, respectively. Therefore, the lunar effect on Sardine CPUE does not seem quite big in Figure 2. The model results show that CPUE decreases slightly with the increasing levels of moon light intensity. Our findings on moon phase effect might be considered as testimonial results about the lunar effects on the schooling behaviour of small pelagic fishes. As a promotive research, the hydro-acoustics study on the diel vertical migration pattern of pelagic fish in a freshwater lake shows that fish biomass in the pelagic zone was $45 \%$ lower during full moon than during new moon (Luecke \& Wurtsbaugh, 1993). Agenbag et al. (2003) also argued that the moon light intensity contributes $0.4 \%$ to the variance explained by the GLM model on purse seine

Table 1. Summary of catch per unit effort (CPUE) statistics of the purse seine fishery of sardine, Sardina pilchardus, in relation to lunar phases.

\begin{tabular}{lcccrrrc}
\hline Moon Phase & N & Min & Max & Mean & Median & SD & SE \\
\hline New Moon & 61 & 0 & 12040 & 2026.8 & 784 & 2564.4 & 328.5 \\
First Quarter & 56 & 0 & 10640 & 1552.5 & 637 & 2144.1 & 286.5 \\
Full Moon & 38 & 0 & 4200 & 885.3 & 441 & 1088.4 & 176.6 \\
Third Quarter & 59 & 0 & 16800 & 2550.1 & 1302 & 3369.2 & 438.6 \\
\hline
\end{tabular}

$\mathrm{SD}=$ standard deviation, $\mathrm{SE}=$ standard error of the mean, $\mathrm{N}=$ number of fishing operations.

Table 2. Analysis of deviance table for the GAM model fitted to the CPUE data of the purse seine fishery.

\begin{tabular}{lccc}
\hline & & \multicolumn{2}{c}{ GAM } \\
\cline { 2 - 4 } Parameter & $\mathrm{df}$ & $\mathrm{F}$ & \\
\hline Moon Phase & 3 & 5.085 & 0.002 \\
Area & 4 & 7.041 & 0.001 \\
Using a light & 1 & 38.097 & 0.001 \\
s(SST) & 1.004 & 26.96 & 0.001 \\
\hline
\end{tabular}

$\mathrm{df}=$ degrees of freedom, $\mathrm{F}=\mathrm{F}$-value, $\mathrm{P}=\mathrm{P}$-value, $\mathrm{s}(\mathrm{x})=$ smoother function of the corresponding independent variable, $\mathrm{SST}=$ sea surface temperature.

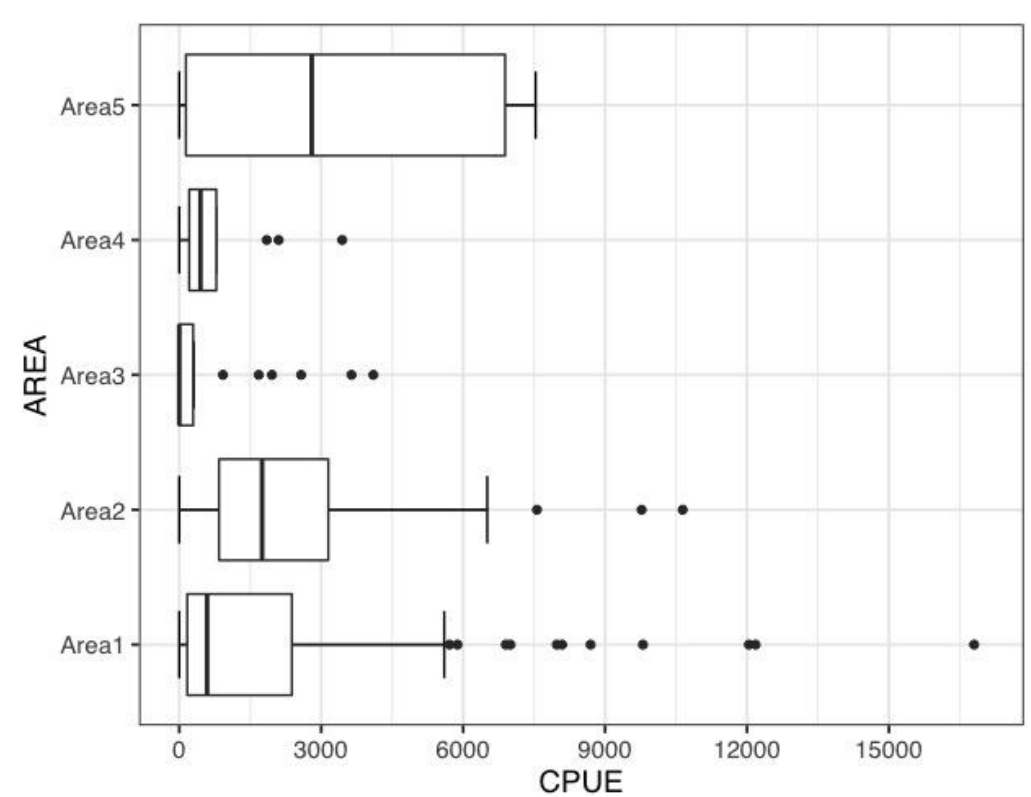

Figure 3. CPUE values of sardine purse seine by areas. 
fishery targeted South African anchovy (Engraulis capensis) and the moon effect showed a similar weak positive trend for positive elevation angles. However, the same authors stated the lunar phase and elevation had no appreciable effect in the GLM of sardine (Sardinops sagax) purse seine fishery. They expressed this situation as sardines are less light-sensitive than anchovies. Furthermore, Poisson et al. (2010) stated that the phases of the moon have a significant influence on CPUE's of longline fishery of some large pelagic fishes such as albacore and swordfish. They also argue that the highest swordfish CPUE occurred during the first and last quarters of the lunar cycle. In contrast, Ceyhan et al. (2018) stated that CPUEs of swordfish longline fishery did not differ significantly between phases of the moon. We think that lunar influences on CPUE are not clearly consistent, owing to various geographical areas, fishing gear and targeted fish. For example, the behaviour of swordfish seems to mimic the movement of mesopelagic organisms in the deep scattering layer, where swordfish feed (Carey, 1990). From our point of our view, the additional parameters (fish behaviour, the

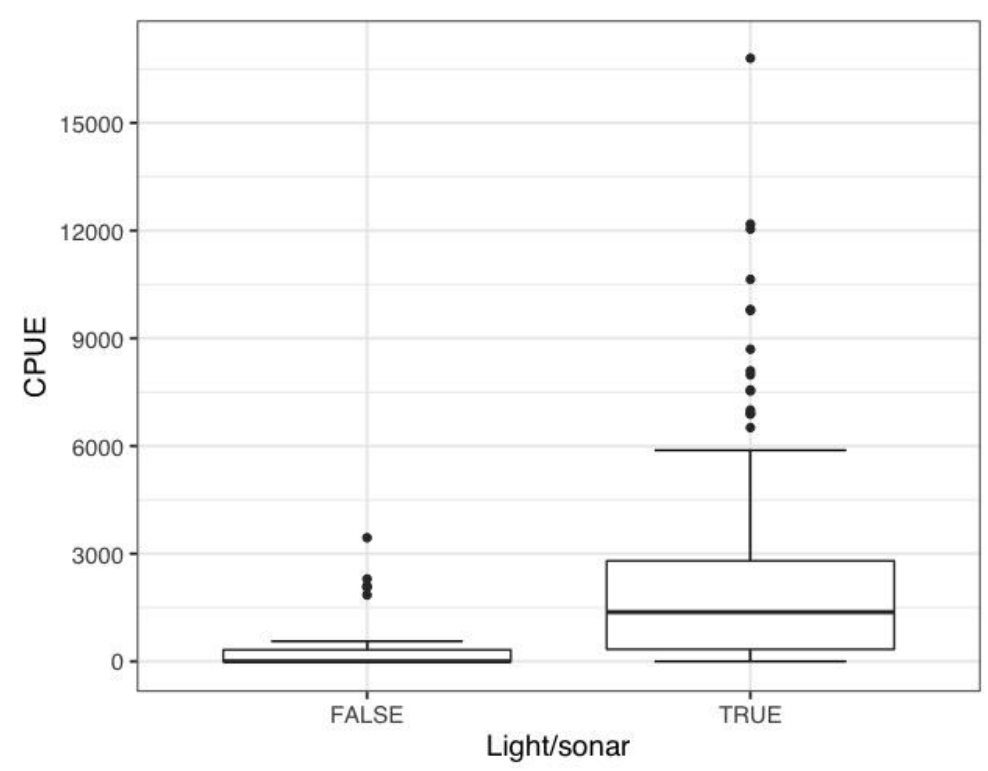

Figure 4. CPUE values of sardine purse seine by using light or sonar detect.
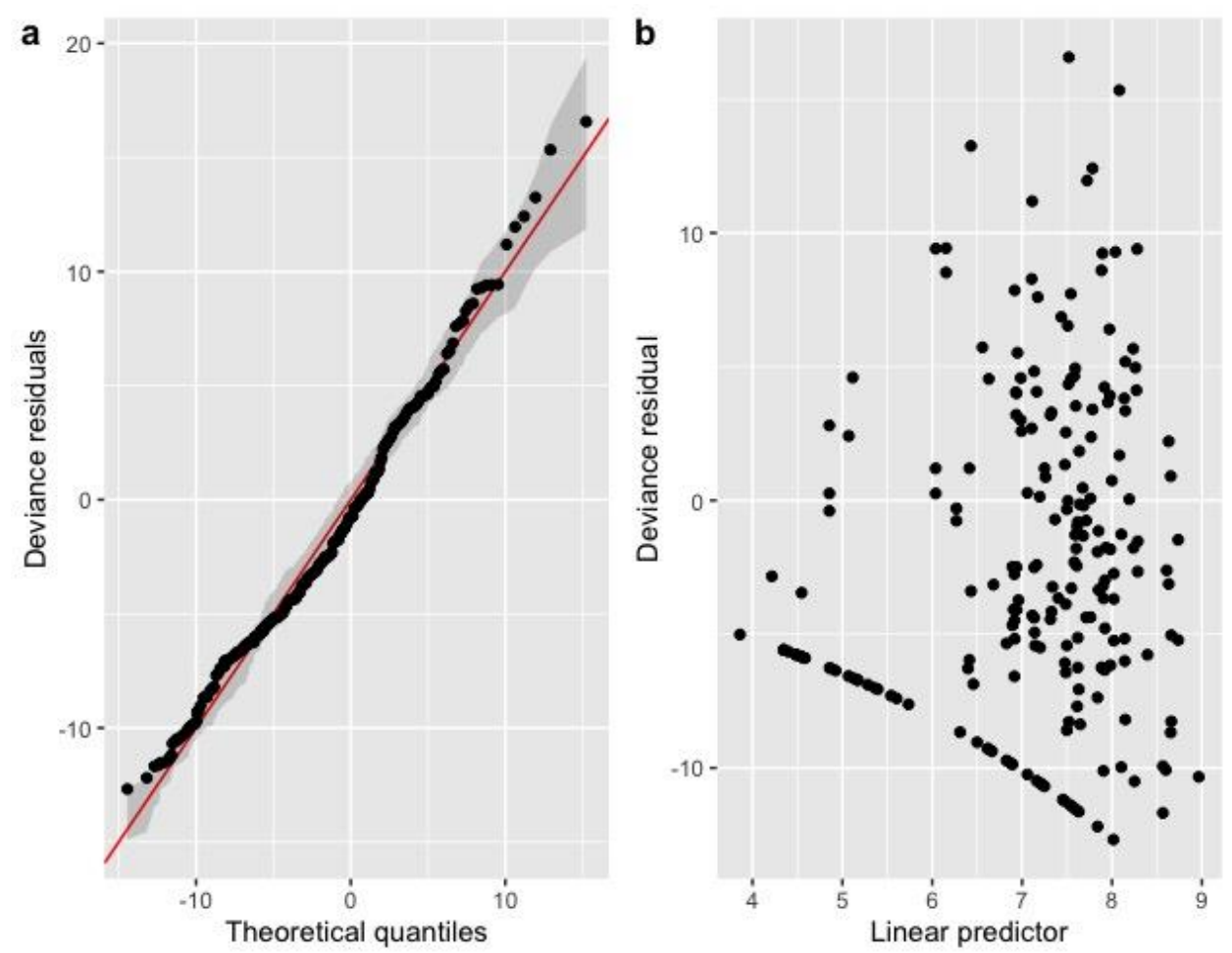

Figure 5. (a) QQ-plot of residuals (black). Red line indicates the 1-1 line and grey bands correspond to the expected $95 \% \mathrm{Cl}$ for the QQ plot. (b) Deviance residuals vs. fitted values. 
features of geographical area, prey abundance etc.) should be considered to clarify the impact of the lunar phase on fishing gear.

In terms of the relationship between CPUE and SST, we found that there was a linear relationship between CPUE and SST (Figure 6), and also this relationship was statistically significant $(p<0.05)$. Although there are a number of studies that had failed to find a relationship between small pelagic fish and SST, Agenbag et al. (2003) found that sardine tends to concentrate in warmer water according to GAM results which provide some insight into the conditions preferred. In fact, Jghab et al. (2019) argue that their linear models reflected a negative relationship between sardine landings and sea surface temperature, sea surface salinity, indicating that the long-term temperature and salinity changes in the Mediterranean could have had a negative impact on sardine abundance. From our point of our view, CPUE and/or landing rates were expected to show the changes for fish abundance in past. In this sense, CPUE and landing data have been derived from the commercial fishery. The depended data may be affected from the many factors such as fleet dynamics, allocation of fishing effort etc. (Hilborn \& Walters, 1992; Harley et al., 2001). The purse seine fishers in the Aegean Sea claim that they catch more sardines when the seawater is warmer between September and November. Abdellaoui et al. (2017) justified this claim by the SST is the most important parameter affecting the abundance of sardine in the Al Hoceima marine area. For this reason, the seasonal variability of CPUE fishing of sardine in the marine area is relatively low from January to May (cold season) and abundant from June to December (warm season) similar to Aegean purse seine fishery. In addition, due to strongly related global warming, the sardine landing has occurred and increased along the Turkish coast of the Black Sea in recent years according to the TurkStat statistics.
As well known, the availability of fish abundance is one of the key factors to realize purse seine operations. Within the framework of this study, the differences between CPUEs of areas are able to be associated with convenience fishing. Thus, purse seiner fleet existed in Area 5 at the beginning of fishing season. After a short duration (a week) of catching, the purse seiner moved to the Izmir Bay to catch sardine mostly in Area 1 and Area 2, that have been directly affected by the Gediz River flows which bring nutrients. In the second term of the catching period (i.e. cold period between 15 December and 15 April), the purse seine shifted its location with Area 3 and Area 4 to catch anchovy, bogue and sardine. The reason of the changing catching area might also be explained by the non-availability of the sardine schools caused by the cooling of the seawater (Abdellaoui et al., 2017).

Fishing with light has become one of the most advanced, efficient, and successful methods for capturing commercially important species on an industrialized scale (Nguyen \& Winger, 2019). In the Aegean Sea purse fishing, catching sardines without using artificial light is never considered, as artificial light plays a key role in gathering sardine schools. Therefore, the mean of CPUE of operations under artificial light sources was found substantially higher (2 217 $\pm 210 \mathrm{~kg}$ (haul day) ${ }^{-1}$ ) compared to the mean of CPUE of operations with sonar $\left.(343 \pm 118 \mathrm{~kg} \text { (haul day) })^{-1}\right)$. Beltestad and Misund (1988) likewise found that herring school was also impossible to catch without using light, as they often remain at a depth of $50 \mathrm{~m}$ and were scattered. When the light was switched on underneath the school, the herring immediately rose towards the surface. As a result, the use of artificial light in purse seine fishing has increased the efficiency of this fishing gear by manipulating the natural behaviour of some commercial pelagic species e.g. sardine, herring.

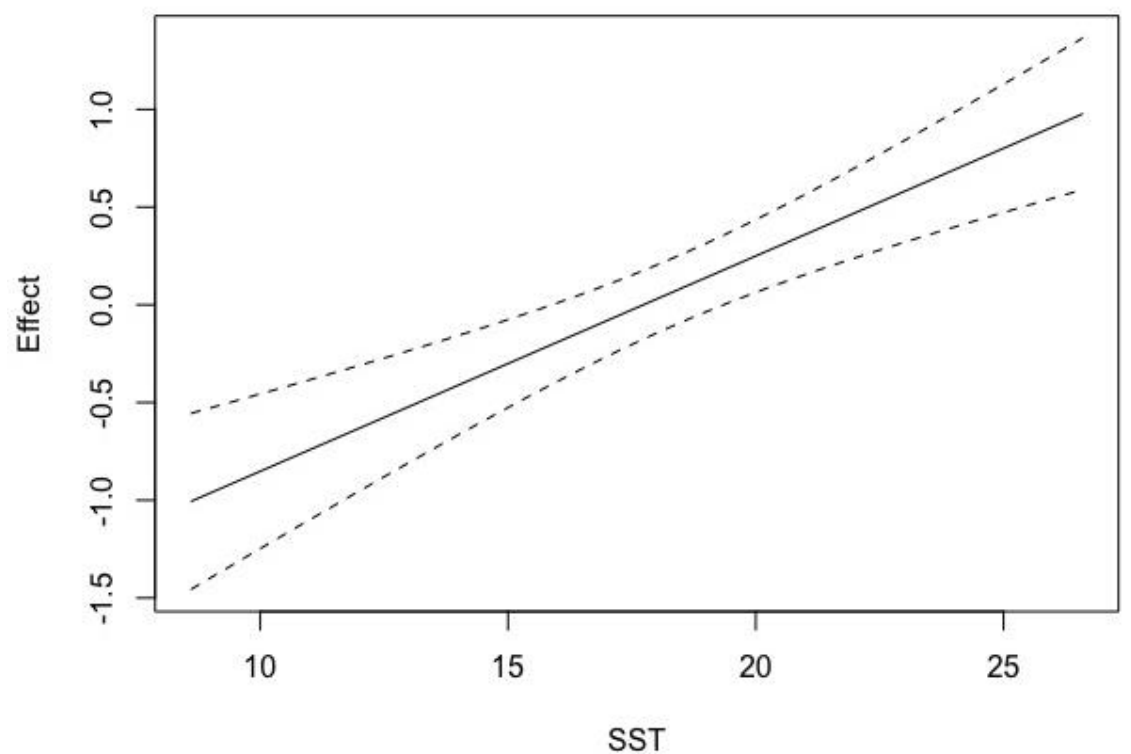

Figure 6. GAM estimated effect of year on CPUE rates for purse seine fishery (dotted lines correspond to the $95 \%$ confidence intervals of the estimates). 


\section{Conclusion}

In the absence of data on this important fishery, this study demonstrates CPUE may vary under hydrographic variables mostly SST in sardine fishery with purse seine in the Aegean Sea. This kind of models would be helpful to understand the spatial and temporal variations of small pelagic fishery. Our results might provide tools to develop or improve the sustainability and management strategies of this fishing, which supports one of the most important fisheries in Turkey. Besides, ecosystem modelling, that includes the climate change and other parameters which cause the fluctuations in stock (Checkley et al., 2017), potential CPUE series that include the reasons as same in this manuscript in large time series would be helpful to predict future states and simulate harvest strategies.

\section{Ethical Statement}

The research was approved by the Ege University Animal Experiments Local Ethics Committee in terms of sampling and use of experimental animals with the decision numbered 2018-004. All researchers declare that all trials were carried out in accordance with ethical values.

\section{Funding Information}

This work was supported by the Scientific and Technological Research Projects Funding Program (TUBITAK - Project No: 1180317)

\section{Author Contribution}

ZT took part in designing the research, collecting data and writing the manuscript. TC analysed all data of the study statistically and writing the manuscript. ÖG and FOD prepared their field studies and references. MHK undertook the editing and application of the article. CA and GM have edited the graphics and figures of the article. All authors took part in a part of the article.

\section{Conflict of Interest}

The authors declare that they have no known competing financial interests or personal relationships that could have appeared to influence the work reported on the paper.

\section{Acknowledgements}

We would like to thanks to Süleyman and Anıl Canbaz owners and skippers of the purse seiner Afala and Mehmet Aksoy Head of the Aegean Region Purse Seine Fishers Association. The present study was prepared from the catch records of the purse seiner Afala, rented for the sieve selectivity and survival samplings of the TUBITAK project (1180317).

\section{References}

Abdellaoui, B., Berraho, A., Falcini, F., Santoleri, J.R., Sammartino, M., Pisano, A., Idrissi, M.H., \& Hilm, K. (2017). Assessing the Impact of Temperature and Chlorophyll Variations on the Fluctuations of Sardine Abundance in Al-Hoceima (South Alboran Sea). Journal of Marine Science: Research \& Development, 7(4), 239. https://doi.org/10.4172/2155-9910.1000239

Agenbag, J.J., Richardson, A.J., Demarcq, H., Fréon, P., Weeks, S., \& Shillington, F.A. (2003). Estimating environmental preferences of South African pelagic fish species using catch size and remote sensing data. Progress in Oceanography, 59, 275-300. https://doi.org/10.1016/j.pocean.2003.07.004

Beltestad, A.K., \& Misund, O.A. (1988). Behaviour of Norwegian spring spawning herring in relation to underwater light. ICES Fish Capture Committee C.M. 1988/8:24 Ref. H, 13 p.

Borges, M.F., Santos, A.M.P., Crato, N., Mendes, H., \& Mota, B. (2003). Sardine regime shifts off Portugal: a time series analysis of catches and wind conditions. Scientia Marina, 67(S1), 235-244.

https://doi.org/10.3989/scimar.2003.67s1235

Carey, F.G. (1990, 1-5 August 1988). Further acoustic telemetry observations of swordfish. In R.H. Stroud (Ed.), Proceedings of the second international billfish symposium, part 2, (pp. 103-122). Natl. Coalition for Mar. Conserv., Savannah, G.A., Kailua Kona, Hawaii.

Checkley Jr., D.M., Asch, R.G., \& Rykaczewski, R.R. (2017). Climate, Anchovy, and Sardine. Annual Review of Marine Science, 9, 469-493. https://doi.org/10.1146/annurevmarine-122414-033819

Ceyhan, T., Tserpes, G., Akyol, O., \& Peristeraki, P. (2018). The effect of the lunar phase on the catch per unit effort (CPUE) of the Turkish swordfish longline fishery in the eastern Mediterranean Sea. Acta Ichthyologica et Piscatoria, 48(3), 213-219. https://doi.org/10.3750/AIEP/02431

Dunn, P.K., \& Smyth, G.K. (2005). Series evaluation of Tweedie exponential dispersion model densities. Statistics and Computing, 15, 267-280.

FAO (2018). The State of Mediterranean and Black Sea Fisheries. General Fisheries Commission for the Mediterranean. Rome, $172 \mathrm{pp}$.

Gang, L.I., Zou, X., Chen, X., Zhou, Y., \& Zhang, M. (2013). Standardization of CPUE for Chilean jack mackerel (Trachurus murphyi) from Chinese trawl fleets in the high seas of the Southeast Pacific Ocean. Journal of Ocean University of China, 12(3), 441-451. https://doi.org/10.1007/s11802-013-1987-1

Gücü, A.C. (2012). Small pelagic fish and fisheries in Turkey. In Tokaç, A., Gücü, A.C., \& Öztürk, B. (Eds.), The State of the Turkish Fisheries, TUDAV No. 35, İstanbul, Turkey, pp. 117.

Harley, S.J., Myers, R.A., \& Dunn, A. (2001). Is catch-per unit effort proportional to abundance? Canadian Journal of Fisheries and Aquatic Sciences, 58(9), 1760-1772. https://doi.org/10.1139/f01-112

Hastie, T.J., \& Tibshirani, R.J. (1990). Generalized additive models. Monographs on Statistics and Applied Probability. Volume 43. Chapman and Hall/CRC, Boca Raton, London, New York, Washington DC.

Hilborn, R., \& Walters, C.J. (1992). Quantitative fisheries stock assessment: Choice, dynamics, and uncertainty. Springer 
Science + Business Media, B.V., Dordrecht.

Hoşsucu, H., Kara, A., Metin, C., Tosunoğlu, Z., \& Ulaş, A. (1994). Purse seine fisheries in Aegean Region and catch effort of the purse seiners (in Turkish with English abstract). Ege Journal of Fisheries and Aquatic Sciences, 11(42-43), 17-32.

Hure, M., \& Mustać, B. (2020). Feeding ecology of Sardina pilchardus considering co-occurring small pelagic fish in the eastern Adriatic Sea. Marine Biodiversity, 50 (40), 112. https://doi.org/10.1007/s12526-020-01067-7

Lecomte, J.B., Benoît, H.P., Ancelet, S., Etienne, M.P., Bel, L., \& Parent E. (2013). Compound Poisson-gamma vs. deltagamma to handle zero-inflated continuous data under a variable sampling volume. Methods in Ecology and Evolution, 4(12), 1159-1166.

https://doi.org/10.1111/2041-210X.12122

Luecke, C., \& Wurtsbaugh, W.A. (1993). Effects of moonlight and daylight on hydro acoustic estimates of pelagic fish abundance. Transactions of the American Fisheries Society, 122(1), 112-120. https://doi.org/10.1577/15488659(1993)122<0112:eomado>2.3.co;2

Jghab, A., Vargas-Yañez, M., Reul, A., Garcia-Martínez, M.C., Hidalgo, M., Moya, F., Bernal, M., Ben Omar, M., Benchoucha, S., \& Lamtai, A. (2019). The influence of environmental factors and hydrodynamics on sardine (Sardina pilchardus Walbaum, 1792) abundance in the southern Alboran Sea. Journal of Marine Systems, 191, 51-63. https://doi.org/10.1016/j.jmarsys.2018.12.002

Nguyen, K.Q., \& Winger, P.D. (2019). Artificial light in commercial industrialized fishing applications: a review. Reviews in Fisheries Science \& Aquaculture, 27(1), 106126. https://doi.org/10.1080/23308249.2018.1496065

Pedersen, E.J., Miller, D.L., Simpson, G.L., \& Ross, N. (2019). Hierarchical generalized additive models in ecology: an introduction with mgcv. PeerJ, 7:e6876 https://doi.org/10.7717/peerj.6876

Poisson, F., Gaertner, J.-C., Taquet, M., Durbec, J.-P., \& Bigelow, K. (2010). Effects of lunar cycle and fishing operations on longline-caught pelagic fish: Fishing performance, capture time, and survival of fish. Fishery Bulletin, 108, 268-281.

R Core Team, (2017). R: A language and environment for statistical computing. $\mathrm{R}$ Foundation for Statistical Computing, Vienna, Austria. http://www.R-project.org

Shono, H. (2008). Application of the Tweedie distribution to zero-catch data in CPUE analysis. Fisheries Research, 93(1-2), 154-162. https://doi.org/10.1016/j.fishres.2008.03.006

Quattrocchi, F., \& Maynou, F. (2017). Environmental drivers of sardine (Sardina pilchardus) in the Catalan Sea (NW Mediterranean Sea). Marine Biology Research, 13(9), 1003-1014.

https://doi.org/10.1080/17451000.2017.1331039

Torrejón-Magallanes, J., Grados, D., \& Lau-Medranoa, W. (2019). Spatio-temporal distribution modeling of dolphinfish (Coryphaena hippurus) in the Pacific Ocean off Peru using artisanal longline fishery data. Deep-Sea Research II, 169-170: 104665.

Tosunoğlu, Z., Aydın, C., Metin, G., Kaykaç, M.H., \& Düzbastılar, F.O. (2018). Researches on Izmir Bay (Aegean Sea, Turkey) purse seine fishery (in Turkish). Ege University Scientific Research Project Coordination Unit, Project No. 2017/SUF/002, 65 p.

TurkStat. (2019). Fishery Statistics 2018 (in Turkish). http://www.turkstat.gov.tr/

Tweedie, M.C.K. (1984). An index which distinguishes between some important exponential families. In J.K. Ghosh and J. Roy (Eds.), Statistics: Applications and New Directions. Proceedings of the Indian Statistical Institute Golden Jubilee International Conference (pp. 579-604). Calcutta: Indian Statistical Institute.

Wise, L., Galego, C., Kataral, I., Marçalo, A., Meirinho, A., Silva, A., Monteiro, S.S., Oliveira, N., Santos, J., Rodrigues, P., Araújo, H., Vingada, J., \& Silva, A. (2019). Portuguese purse seine fishery spatial and resource overlap with top predators. Marine Ecology Progress Series, 617-618, 183-198. https://dx.doi.org/10.3354/meps12656

Wood, S.N. (2006). Generalized additive models: An introduction with R. Chapman and Hall/CRC, Boca Raton, London, New York

Wood, S.N., Pya, N., \& Saefken, B. (2016). Smoothing parameter and model selection for general smooth models. Journal of the American Statistical Association, 111(516), 1548-1563. https://doi.org/10.1080/01621459.2016.1180986

Yang, S-L., Fan, X-M., Wu, Y-M., Zhou, W-F., Wang, F. et al., 2019. The relationship between the fishing ground of mackerel (Scomber australasicus) in Arabian Sea and the environment based on GAM model (in Chinese with English abstract). Chinese Journal of Ecology, 38(8), 2466-2470.

https://doi.org/10.13292/j.1000-4890.201908.032 